\title{
Determinants of Regulatory Burdens on Non-Listed Small Corporations in Australia: Perceptions of Small Corporations' Owners/Managers
}

\author{
Yongqiang Li, Anona Armstrong and Andrew Clarke \\ Victoria University, Australia
}

\begin{abstract}
Small corporations are the engine room whilst the forgotten corner of the Australian economy. Regulatory burdens are hampering the small corporations from performing to their optimal, which consequently impairs the economic growth of the nation. For policy decision makers, quantifying the regulatory compliance cost is the first priority for evidence-based de-regulatory reforms. Thus, policy options proposed are of practical imperative to future de-regulation reforms. Prior research supporting the estimation and determination of regulatory compliance cost are at a dearth. This paper fills the gap by estimating the regulatory compliance costs of small corporations using the firm level survey data. A non-parametric logit model, Generalised Ordered Logit/Partial Proportional Odds Model (gonlogit2), is developed to estimate the impacts of determinants on regulatory costs. The paper concluded with a discussion of policy implications and future research directions.
\end{abstract}

\section{Key words}

Regulatory compliance costs, generalised ordered logit model, small corporations

\section{Introduction}

The issue of exhibitive regulatory compliance cost and its adverse effect on businesses have been noted by governments and appealed by the business

Copyright (C) 200x Victoria University. This document has been published as part of the Journal of Business Systems, Governance and Ethics in both online and print formats. Educational and non-profit institutions are granted a nonexclusive licence to utilise this document in whole or in part for personal or classroom use without fee, provided that correct attribution and citation are made and this copyright statement is reproduced. Any other usage is prohibited without the express permission of the publisher. community in the past decades worldwide reported in the World Bank report (Loayza and Serven 2010). In Australia, the Australian Chamber of Commerce and Industry in 2005 estimated that myriads of regulatory compliance requirements cost Australian businesses \$86 Billion annually, accounting for $10.2 \%$ of the GDP (ACCI 2005). The former chairman of Australian Competition and Consumer Commission, Alan Fels told the Australian Financial 
Review that, "despite the ideology of deregulation, the fact is regulation has been increasing for the last 70 years" (Kehoe 2010).

Regulatory reforms have been undertaken by various levels of governments in Australia in the past decades. However, there is still little evidence articulating the potential impact of regulatory on the performance of small corporations. Neither is any evidence on the determination of the regulatory costs, which may be minimised by properly designed regulatory reform vehicles. Failure to understand how regulation affects business means that policy interventions are likely to produce unwanted consequences because they do not identify the full range of mechanisms shaping small business performance nor the conditions which support or hinder the exercise of these mechanisms and the generation of their expected effects.

\section{Definition of regulation}

The regulation of business activity is a key issue for national Governments and supranational policymakers alike (OECD 2003). The former Ministry of Small Business in Australia, Mr. Nick Sherry commissioned the Production Commission to undertake an investigation that identifies the potential regulatory reform opportunities on 12 May, 2011 (Productivity Commission 2011). The Productivity Commission (2011) defined regulation as

"a principle, rule, or law designed to control, govern or influence conduct. Regulatory instruments shape incentives and influence how people behave and interact, helping societies to function well and deal with a variety of problems".

Regulation can be broadly divided into economic regulation (which can directly influence market behaviour such as pricing, competition, market entry or exit) and social regulation (which protects public interests such as health, safety, the environment and social cohesion). Some economic and social regulations apply widely to the community, while others apply only to certain industries.

Regulatory instruments in Australia can also be classified according to their legal basis:

- Primary legislation consists of Acts of Parliament. (A legislative proposal for enactment of a law is called a Bill until it is passed and receives a Royal Assent, at which time it is a law (statute) and is no longer referred to as a Bill.)

- Statutory rules are any regulations made under enabling legislation, with a requirement to be tabled in Parliament and/or be assented to by the Governor or Governor General-in-Council.

- Other legislative instruments include guidelines, declarations, orders or other instruments that have legal enforceability, but that are not subject to Parliamentary scrutiny.

Apart from these regulatory instruments, there are also codes and standards that governments use to influence behaviour, but which do not involve 'black letter' law - these are known as quasi-regulation. Forms of co-regulation, such as legislative support for rules developed and administered by industry, and other instruments such as international treaties, are also used to directly or indirectly influence conduct (PC 2008).

\section{Definition of regulatory compliance cost}

The regulatory compliance cost is defined as "all the costs incurred directly or indirectly by regulators". Marneffe and Vereeck (2011) identified sixteen direct and two indirect regulatory cost types. The direct costs are costs borne by society in preparing and implementing regulations. For the government, they consist of information, decision-making, drawing-up, planning, administrative start-up, operational, monitoring, and enforcement costs. Citizens and businesses, on the other hand, incur rent-seeking, 
information, planning, three types of compliance, delay and enforcement costs. The indirect costs comprise the efficiency loss plus, in the event of poorly designed or market-based regulation, also transaction costs.

\section{Definition of small corporations in Australia}

This study adopts the definition of small corporations from The Corporations Act 2001 section 45 . A small corporation is defined as one which has less than 50 shareholders and satisfying 2 out of 3 criteria in a financial year:

- consolidated gross revenue of less than $\$ 25$ million;

- value of consolidated gross assets less than $\$ 12.5$ million; and

- fewer than 50 full-time equivalent employees.

Small corporations are the engine room of the Australian economy. In Australia during 2009/10, more than $99 \%$ of businesses are small corporations. The small corporations employ more than $60 \%$ of the workforce and contribute to about $46 \%$ of the national GDP. More than $70 \%$ of the Research and Development (R\&D) are undertaking by the small corporations (Armstrong et al. 2011).

Though small corporations play a vital role in Australia, they are particularly disadvantaged from enjoying the spill-over effect of government regulatory reforms. Contingencies, i.e. business size, resource limitation, lack of access to finance, skill shortage, lack of power and influence to lobby, constrains small corporations from performing to their optimal (Armstrong et al. 2011). Obviously, the gap between the ideal policy design and practical innate difficulties of small corporations signals an unmet need of reducing regulatory burdens for the small corporations.

\section{Research question}

To provide better evidence for the reduction of regulatory burdens of small corporations in Australia, finding answers to the following research question is critical.

\section{What are the determinants of regulatory compliance costs of small corporations in Australia?}

Given that the small corporations section has been ignored The paper intends to contribute to the literature in three aspects, (1) a simple metric is developed to measure the regulatory compliance cost borne by small corporations in Australia; (2) rigid empirical approach has been adopted to estimate the impacts of determinants of regulatory compliance costs; (3) based on the empirical findings, policy options are proposed to reduce the regulatory burdens. To such ends, this paper is mainly focused on the determinants of regulatory compliance costs self-reported by small corporations from the survey, which is largely financial costs, whilst that the distinction of finer level compliance costs, i.e. administrative, substantiative and social costs (Kitching 2010), are to be assumed by future endeavours.

The rest of the paper proceeds as follows, Section two reviews the literature pertinent to the determinants of regulatory burdens, and hence hypothesis are developed; Section three describes the data and econometric models; results are reported and discussed in Section four; Section five concludes by responding to the hypotheses and future work. 


\section{Literature review and hypothesis}

The literature on determinants of regulatory compliance costs can be divided into five streams, including business size, business characteristics, owner characteristics, decision making tools, and CSR.

Relatively larger businesses (in relation to turnover or the number of employees) bear larger compliance costs for small businesses and the relative burden is higher for small businesses comparing with the large corporations (Sandford et al. 1989). Sandford further suggested that the first employee will significantly result in a "jumping up" of regulatory costs because of the abrupt increment in fix cost.

\section{H1: The growth of business size increases compliance costs.}

The business characteristics are also critical to the compliance cost. It is expected that younger businesses bear higher compliance costs because of the start up costs and learning curve effects (Rametse and Pope 2002; Tran-Nam and Glover 2002).

\section{H2: Younger businesses bear more compliance costs.}

In Australia, each state assumes legislative and regulatory power as well, which makes the location of business pertinent to compliance costs (PC 2009, 2011).

\section{H3: Location has an impact on compliance cost.}

Different industry structure means different regulatory compliance obligations to comply with. Thus, industry is expected to have a significant impact on the compliance cost (Allers 1994).

\section{H4: Industry has a significant impact on compliance cost.}

Different legal type has profound implications on regulatory compliance requirements. The endowment of human capital and financial proficiency enables the large corporations to meet the compliance requirements easily, minimising the possibility of being penalised. In addition, the large corporations enjoy the power to lobby and negotiate with the regulators, which leaves the small corporations into a disproportionately disadvantaged position (Armstrong et al. 2011). This line of argument suggests that the small corporation, in particular private companies, on average, bears more unnecessary ${ }^{11}$ compliance costs. On contrary, a group of researchers, based on the complexity of the organisation structure per se, argued that small corporations, i.e. individual firms, should incur lower compliance costs (Standford and Hasseldine 1992; DeLuca et al. 2005).

\section{H5: Legal type has a significant impact on compliance cost.}

The seven business development stages, including seed stage, start-up stage, growth stage, established stage, expansion stage, decline stage and exit stage, on the business life cycle influences the compliance cost (AG 2007).

\section{H6: Business development stage has a significant impact on compliance cost.}

\footnotetext{
11 "Unnecessary" means there is little justification for the regulation to be introduced to the small corporations in the first place. Consequently, the small corporations are bearing the unintended costs of "one size fit all" model.
} 
The characteristics of business owners affects the perception of them on regulatory requirements, thus the characteristics of business owners are expected to have a significant impact on compliance cost.

\section{H7: Characteristics of business owners/managers has a significant impact on compliance cost.}

Marneffe and Vereeck (2011) identified planning, innovation, ICT and social responsibilities extra burdens to all the business entities and thus incur regulatory compliance costs.

H8: ICT has a significant impact on compliance costs.

H9: Innovation has a significant impact on compliance costs.

H10: Strategic planning has a significant impact on compliance costs.

H11: Concerns of small corporations with different stakeholders, including customers, suppliers, investors, employees, philanthropy and environment, have significant impacts on compliance costs.

Armstrong et al (2011) found that small corporations which are members of industry associations tend to incur less compliance costs than those which are not members.

H12: Small corporations which are members of industry associations has a negative impacts on their compliance costs.

\section{Data and econometric models}

A convenient sampling approach has been adopted to collect data from an online survey during 2010/11. Small corporations from Australia-wide were invited by numerous industry associations to participate in the survey. The online survey collected 391 responses.

The survey was designed based on literature review and feedback from the experts. The survey covers questions on business size, i.e. number of full-time equivalent employees and total assets; business characteristics, including age of business, industry, location of the business, whether the small corporation is a member of an industry association, legal form, stage on the sever-stage business development cycle; owner characteristics, i.e. prior experience as a owner/manager of the business, education background, gender and age; strategic decision making tools, including information and communication technology (ICT), expenditure on innovation, strategic plan; and corporate social responsibility (CSR), such as customers, suppliers, employees, investors, philanthropy and environment. A detailed description of variables can be found in Table 1 (Appendix 1).

Based on the literature, the relationship between compliance cost and its determinants can be put as

$$
\mathrm{P}\left(\mathrm{Y}_{\mathrm{i}}\right)=\mathrm{f}\left(\mathrm{x}_{\mathrm{i}}\right)+\xi_{\mathrm{i}}
$$

, where $Y_{i}$ is the compliance cost, $x_{i}$ is a vector of determinants, $\xi_{\mathrm{i}}$ is the error term. Compliance cost is the dependent variable and the rest of the variables serve as independent variables.

Given that all the variables are categorical variables and the dependent variable is nominal variable, the Generalised Ordered Logit Model (gologit) is chosen as the specification for the analysis. Following William (2006), Eq. (2) can be re-written as

$, j=1,2, \ldots, M-1$ 
, where $\mathrm{M}$ is the number of categories of the ordinal dependent variable.

Stata12.0 is used to estimate the Generalised Ordered Logit model, including both gologit and gologit2. Maximum-likelihood is the estimator for all the computations.

\section{Results and discussion}

\section{Descriptive statistics}

The summary statistics have been reported in Table 2 (Appendix 2). Due to the missing value issue, less than 200 complete records are available for the modelling exercise.

\section{Spearman's rank correlation coefficients}

Given that all the variables included in the analysis are categorical variables, Spearman's rank correlation coefficients computation is applied( Refer to Table 3 , Appendix 3).

The days on regulatory compliance is positively related to business development stage, meaning that the more mature the business is, the more compliance cost is incurred, ceteris paribus. Strategic plan and having a focus on suppliers negatively correlated with the compliance cost. Full-time equivalent employee number is positively correlated with business development stage, indicating that the more mature the business is, the more staff small corporations are hiring.

The prior experience of the owner/manager is positively correlated with total assets, meaning that the longer the business decision maker has been in place, the larger the business is. The legal form is positively correlated with the prior experience of the owner/manager, indicating that experienced owner/managers prone to use private companies as the legal form of the business.

Small corporations which care about customers also care about employees and the environment.

\section{Goodness of fit and validity tests}

Both McFadden's R2 and ML (Cox-Snell) R2 indicates the models identified have acceptable R2 values. The Chi2 value, as well as the corresponding p-value, indicates that all the models identified are valid (Refer to Table 4, Appendix 4).

An additional assumption in ordinal logistic modelling is that proportional odds, or parallel lines assumption. All the models identified passed the Wald test, thus violation of parallel lines assumption is not a concern.

\section{Econometric modelling results}

Generalised ordered logit model takes up business characteristics, owner characteristics, decision making techniques, and CSR respectively in model 1-4, using business size as the control variable. Model 5 includes all the five strands of factors. The modelling results are reported in Table 5 (Appendix 5).

\section{Business size}

Employee number is a positive and significant factor for compliance cost. However, the total assets, or size in financial terms, are not significant. H1 has been accepted. Thus, the small corporations with greater number of employees, ceteris paribus, have a higher likelihood to incur more compliance costs. 


\section{Business characteristics}

The location of business is a positive and significant factor for compliance cost, meaning that, ceteris paribus, relocation of the business may possibly incur extra compliance costs to the business. H3 is accepted.

Being a member of an industry association is a negative and significant factor for compliance cost. On average, small corporations which are members of industry associations tends to incur less compliance costs than small corporations which are not members, keeping the other factors constant. Being a member of an industry association may facilitate the small corporations to expose to regulatory requirements transferred by their industry associations and may communicate good practice of tackling with regulatory requirements. H12 is accepted.

\section{Owner characteristics}

Gender of the owner/manager is a negative and significant factor for compliance cost. In this paper, gender is coded as 1 if it is male, 2 if female. Thus, small corporations having a female owner/manager tend to have less compliance cost, comparing with those having male owner/managers. $\mathrm{H} 7$ is accepted.

\section{Decision making}

ICT is a negative and significant factor for compliance cost, meaning that small corporations adopting new ICT techniques tends to have less compliance cost, keeping the other factors constant. H8 is accepted.

\section{CSR}

Small corporations concerning with suppliers has a significant and negative impact on compliance costs. This may because the suppliers are easing the process of meeting regulatory requirements in some ways. H11 is accepted.

The econometric model failed to accept the other hypotheses.

The empirical findings may support policy design toward targeted reduction on regulatory compliance costs, i.e. boosting the application of ICT in small corporations, promoting the role industry associations should play.

\section{Conclusion and future work}

This paper analysed the regulatory compliance costs using firm level data. Determinants of compliance costs are estimated using econometric modelling techniques. Factors identified to be statistically significant to compliance costs include employee numbers, location, being a member of an association, gender of the owner, ICT, regarding suppliers as important stakeholders.

This study is subjected to three limitations: (1) a static perspective has been applied in the analysis due to the availability of the data; (2) regulatory compliance cost is simply measured by the financial cost selfreported by the owners of small corporations; (3) missing value is a challenge as well.

Future work should endeavour to collect a longitudinal firm level data with a focus on compliance costs; and develop a regulatory compliance cost index to quantify the compliance costs from a multidimensional perspective, coupled with the analysis of qualitative data. In addition, computation approach, i.e. multiple imputations, may be used to handle the missing data problem. 


\section{Reference}

Allers, M. (1994) Administrative and compliance costs of taxation and public transfers in the Netherlands, Wolters-Noordhoff, Groningen.

Armstrong, A., A., Clarke, Y., Li, K., Heenetigala et al. (2011) Developing a Responsive Regulatory System for Australia's Small Corporations. Governance Program, Victoria Law School, Melbourne, Australia, ISBN: 978-1-86272-692-5.

Attorney-General's Department of Commonwealth Government of Australia (AG) (2007) Scoping study of small business tax compliance costs, internet access under http://www.taxboard.gov.au/content/reviews and consultations/small business tax compliance cost s/scoping study report/downloads/small business tax compliance costs scoping study.pdf.

Australian Chamber of Commerce and Industry (ACCI) (November, 2005). Media Release: Regulation Costs Australia \$86 Billion Annually

DeLuca, D. , A., Greenland, J., Guyton, S. Hennessy and A., Kindlon (2005) Measuring the tax compliance burden of small businesses, in: SOI Tax Stats -Papers - 2005 IRS Research Conference, 75-95, internet access under http://www.irs.gov

Kehoe, J. (18 May, 2010) Government strangles red tape promise, The Australian Financial Review.

Kitching, J. (2010) Book Review of: Business regulation and public policy: the costs and benefits of compliance by Andre Nijsen, John Hudson, Christoph Muller, Kees van Paridon and Roy Thurik (eds). International Small Business Journal, 28(1), pp. 125-127. ISSN (print) 0266-2426

Loayza, N. and L. Serven (2010). Business regulation and economic performance. Washington, DC, World Bank.

Marneffe, W. and L. Vereeck (2011). The meaning of regulatory costs. European Journal of Law and Economics 32(3): 341-356.

Organisation for Economic Co-operation and Development (OECD) (2003) From Red Tape to Smart Tape: Administrative Simplification in OECD Countries, available at: http://www.oecd.org/topic/0,2686,en $264937421 \quad 1 \quad 1 \quad 1 \quad 1 \quad 37421,00 . h t m l$

Productivity Commission (PC) (2008) Benchmarking the regulatory burdens. Project report.

Productivity Commission (PC) (2011) Identifying and evaluating regulatory reforms. Project report.

Rametse, N., J. Pope (2002) Start-up tax compliance costs of the GST: Empirical evidence from Western Australian small business, Australian Tax Forum, Vol. 17, 407-442

Sandford, C., M., Godwin, and P. Hardwick (1989) Administrative and compliance costs of taxation. Fiscal Publications, Bath.

Sandford, C., J., Hasseldine (1992) The compliance costs of business taxes in New Zealand, Institute of Policy Studies: Wellington

Tran-Nam, B., J. Glover (2002) Estimating the transitional compliance costs of the GST in Australia: A case study approach, Australian Tax Forum, Vol. 17, 499-536

Williams, R. (2006) Generalized Ordered Logit / Partial Proportional Odds Models for Ordinal Dependent Variables. The Stata Journal 6(1):58-82. 


\section{Appendix 1 Table 1 Definitions of variables}

\begin{tabular}{|c|c|}
\hline Variable & Definition \\
\hline $\begin{array}{l}\text { Days spent on regulatory } \\
\text { compliance }\end{array}$ & Number of days the business spent on meeting regulatory compliance requirements. \\
\hline employee number & Number of full-time equivalent employees, ordinal value \\
\hline total assets & Total assets, ordinal value \\
\hline age of business & Number of years since the firm was established, interval value \\
\hline industry & Which industry the business is in, nominal value \\
\hline location of state & Which state the business is in, nominal value \\
\hline member of an association & Whether the business is a member of an industry association, binary value \\
\hline legal form & Which legal form is the business, nominal value \\
\hline business development stage & One of the sever business development stages, nominal value \\
\hline $\begin{array}{l}\text { prior experience of the } \\
\text { owner/manager }\end{array}$ & Years being as the business owner/manager, ordinal value \\
\hline $\begin{array}{l}\text { education level of the } \\
\text { owner/manager }\end{array}$ & Education level, ordinal value \\
\hline $\begin{array}{l}\text { gender of the } \\
\text { owner/manager }\end{array}$ & Male or female, nominal value \\
\hline age of the owner/manager & Age, ordinal value \\
\hline ICT & Whether ICT is important to the business, binary value \\
\hline innovation & Percentage of expenditure on innovation, ordinal value \\
\hline strategic plan & Whether the business has a strategic plan in place, binary value \\
\hline customers & Whether the business regard customers as an important factor for the business performance binary value \\
\hline suppliers & Whether the business regard suppliers as an important factor for the business performance, binary value \\
\hline employees & Whether employees are an important factor for the business performance \\
\hline investors & Whether the business regard investors as an important factor for the business operation, binary value \\
\hline philanthropy & Whether philanthropy is an important factor for the business performance, binary value \\
\hline environment & Whether is an important factor for the business performance, binary value \\
\hline
\end{tabular}


Appendix 2 Table 2 Summary statistics

\begin{tabular}{|c|c|c|c|c|c|}
\hline Variable & $\mathbf{N}$ & Mean & Std Dev & Min & Max \\
\hline days on regulatory compliance & 391 & 2.757033 & 1.567227 & 1 & 6 \\
\hline employee number & 206 & 2.5 & 0.981537 & 1 & 5 \\
\hline total assets & 391 & 1992.074 & 16.66401 & 1884 & 2011 \\
\hline age of business & 391 & 11.59335 & 5.487128 & 1 & 19 \\
\hline industry & 391 & 2.176471 & 1.475287 & 1 & 10 \\
\hline location of state & 391 & 1.265985 & 0.442422 & 1 & 2 \\
\hline member of an association & 391 & 2.429668 & 0.831767 & 1 & 5 \\
\hline legal form & 391 & 4.28133 & 1.119814 & 1 & 7 \\
\hline business development stage & 205 & 5.204878 & 3.583319 & 1 & 16 \\
\hline prior experience of the owner & 391 & 3.987212 & 1.265859 & 1 & 5 \\
\hline education level of the owner & 391 & 3.736573 & 1.765675 & 1 & 8 \\
\hline gender of the owner & 391 & 1.276215 & 0.447697 & 1 & 2 \\
\hline age of the owner & 391 & 2.705882 & 1.02679 & 1 & 5 \\
\hline ICT & 196 & 1.204082 & 0.404061 & 1 & 2 \\
\hline innovation & 205 & 3.682927 & 1.968365 & 1 & 9 \\
\hline strategic plan & 209 & 1.569378 & 0.496352 & 1 & 2 \\
\hline customers & 203 & 1.068966 & 0.254022 & 1 & 2 \\
\hline suppliers & 199 & 1.281407 & 0.45082 & 1 & 2 \\
\hline employees & 202 & 1.094059 & 0.292637 & 1 & 2 \\
\hline investors & 391 & 2.332481 & 0.752394 & 1 & 3 \\
\hline philanthropy & 391 & 2.350384 & 0.725007 & 1 & 3 \\
\hline environment & 391 & 2.163683 & 0.893745 & 1 & 3 \\
\hline
\end{tabular}




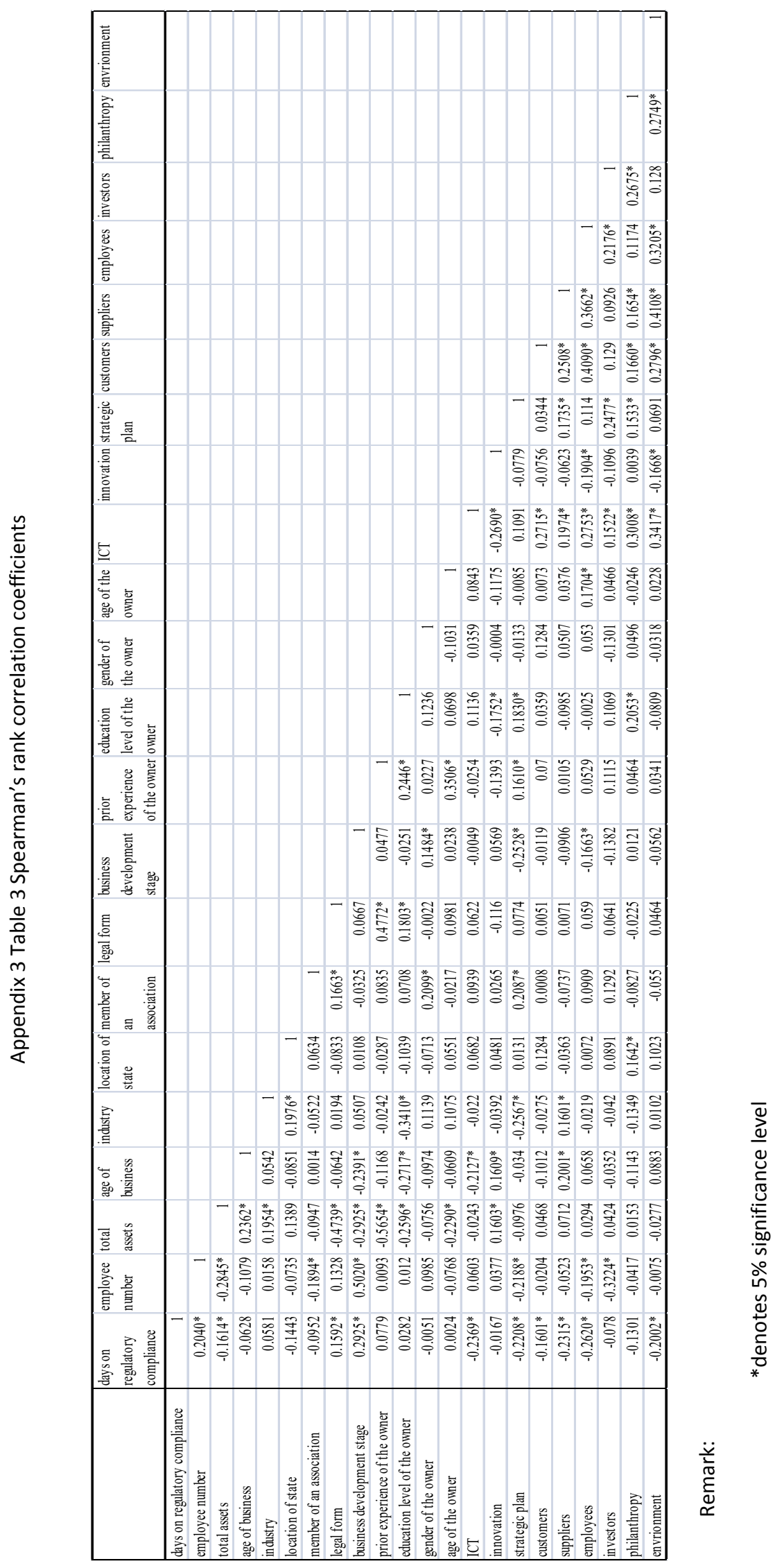


Appendix 4 Table 4 Goodness of fit results

\begin{tabular}{|l|l|l|l|l|}
\hline Model & Chi2 & $p$-value & McFadden's R2 & ML (Cox-Snell) R2 \\
\hline Model 1 & 96.95 & 0 & 0.152 & 0.392 \\
\hline Model 2 & 45.429 & 0.035 & 0.071 & 0.208 \\
\hline Model 3 & 59.405 & 0 & 0.102 & 0.281 \\
\hline Model 4 & 125.786 & 0 & 0.212 & 0.497 \\
\hline Model 5 & 271.770 & 0 & 0.468 & 0.781 \\
\hline
\end{tabular}


Appendix 5 Table 5 Econometric results

\begin{tabular}{|c|c|c|c|c|c|c|}
\hline $\begin{array}{l}\text { Dependent } \\
\text { variable }\end{array}$ & $\begin{array}{l}\text { days spent on meeting regulatory } \\
\text { compliance requirements }\end{array}$ & Model 1 & Model 2 & Model 3 & Model 4 & Model 5 \\
\hline \multirow[t]{4}{*}{ business size } & employee number & $0.547^{*}$ & 0.421 & 0.36 & 0.502 & 0.403 \\
\hline & & $(-2)$ & $(-1.78)$ & $(-1.48)$ & $(-1.92)$ & $(-1.07)$ \\
\hline & total assets & 0.0641 & 0.0797 & 0.065 & 0.0502 & 0.0862 \\
\hline & & $(-1.09)$ & $(-1.41)$ & $(-1.13)$ & $(-0.86)$ & $(-1.03)$ \\
\hline \multirow{12}{*}{$\begin{array}{c}\text { business } \\
\text { characteristics }\end{array}$} & age of business & -0.00715 & & & & -0.0166 \\
\hline & & $(-0.41)$ & & & & $(-0.62)$ \\
\hline & industry & 0.00742 & & & & 0.107 \\
\hline & & $(-0.21)$ & & & & $(-1.95)$ \\
\hline & location of state & $0.510^{*}$ & & & & $0.897 * *$ \\
\hline & & $(-2.45)$ & & & & $(-2.87)$ \\
\hline & member of an association & $-0.908^{*}$ & & & & $-1.261^{*}$ \\
\hline & & $(-2.24)$ & & & & $(-2.15)$ \\
\hline & legal form & -0.233 & & & & -0.299 \\
\hline & & $(-1.00)$ & & & & $(-0.92)$ \\
\hline & business development stage & -0.103 & & & & -0.532 \\
\hline & & $(-0.57)$ & & & & $(-1.91)$ \\
\hline \multirow{8}{*}{$\begin{array}{c}\text { owner } \\
\text { characteristics }\end{array}$} & prior experience of the owner & & 0.137 & & & 0.413 \\
\hline & & & $(-0.93)$ & & & $(-1.3)$ \\
\hline & education level of the owner & & 0.00688 & & & 0.0831 \\
\hline & & & $(-0.07)$ & & & $(-0.56)$ \\
\hline & gender of the owner & & -0.765 & & & $-1.745^{*}$ \\
\hline & & & $(-1.84)$ & & & $(-2.48)$ \\
\hline & age of the owner & & -0.185 & & & -0.384 \\
\hline & & & $(-1.06)$ & & & $(-1.50)$ \\
\hline \multirow[t]{6}{*}{ Decision making } & ICT & & & $-1.146^{* *}$ & & -0.0784 \\
\hline & & & & $(-2.75)$ & & $(-0.12)$ \\
\hline & innovation & & & -0.0221 & & 0.024 \\
\hline & & & & $(-0.23)$ & & $(-0.17)$ \\
\hline & strategic plan & & & -0.479 & & 0.446 \\
\hline & & & & $(-1.29)$ & & $(-0.74)$ \\
\hline \multirow[t]{10}{*}{ CSR } & customers & & & & -1.128 & -0.486 \\
\hline & & & & & $(-1.52)$ & $(-0.50)$ \\
\hline & suppliers & & & & $-1.235^{* *}$ & -0.78 \\
\hline & & & & & $(-2.89)$ & $(-1.30)$ \\
\hline & investors & & & & 0.348 & -0.312 \\
\hline & & & & & $(-0.92)$ & $(-0.50)$ \\
\hline & philanthropy & & & & -0.275 & -0.559 \\
\hline & & & & & $(-0.64)$ & $(-0.91)$ \\
\hline & enviornment & & & & -0.152 & -0.065 \\
\hline & & & & & $(-0.40)$ & $(-0.12)$ \\
\hline \multirow{2}{*}{\multicolumn{2}{|c|}{ constant }} & 14.58 & 0.384 & 1.932 & $2.269^{*}$ & 36.97 \\
\hline & & $(-0.42)$ & $(-0.39)$ & $(-1.86)$ & $(-2.04)$ & $(-0.68)$ \\
\hline & $\mathrm{N}$ & 195 & 195 & 180 & 183 & 179 \\
\hline \multicolumn{7}{|c|}{\begin{tabular}{l|l} 
Remarks & \\
\end{tabular}} \\
\hline \multicolumn{7}{|c|}{ (1) t statistics are in parentheses; } \\
\hline \multirow{2}{*}{\multicolumn{7}{|c|}{$\begin{array}{l}\text { (2) * } p<0.05, * * p<0.01, * * * p<0.001 \\
\text { (3) Model 1-3 are estimated using gologit2 techni }\end{array}$}} \\
\hline & & ; Model 4 & & & & le to the \\
\hline \multicolumn{7}{|c|}{ constraint of computation compacity. } \\
\hline
\end{tabular}


